\title{
Streptomyces radiopugnans sp. nov., a radiation-resistant actinomycete isolated from radiation-polluted soil in China
}

\author{
Jun Mao, ${ }^{1}$ Oiyong Tang, ${ }^{1}$ Zhidong Zhang, ${ }^{1}$ Wei Wang, ${ }^{1}$ Dong Wei, \\ Ying Huang, ${ }^{2}$ Zhiheng Liu, ${ }^{2}$ Yuhu Shi ${ }^{1}$ and Michael Goodfellow ${ }^{3}$
}

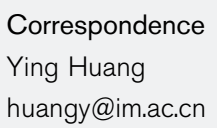

The first radiation-resistant micro-organism to be described, designated 'Micrococcus radiodurans', was isolated from irradiated meat (Anderson et al., 1956) and was subsequently reclassified as Deinococcus radiodurans (Brooks \& Murray, 1981). Other notable radiation-resistant bacteria include Bacillus nealsonii (Venkateswaran et al., 2003), Hymenbacter actinosclerus (Collins et al., 2000), Trueperia radiovictrix (Albuquerque et al., 2005) and the actinobacteria Kineococcus radiotolerans (Phillips et al., 2002) and Rubrobacter taiwanensis (Chen et al., 2004). During a study on the bioremediation of radiation-contaminated soils in Xinjiang Province, China, a radiation-resistant streptomycete-like strain, designated $\mathrm{R} 97^{\mathrm{T}}$, was isolated. The present study was designed to determine the taxonomic status of this organism by using genotypic and phenotypic procedures. The resultant data show that the strain should be classified as representing a novel species of the genus Streptomyces.

The GenBank/EMBL/DDBJ accession number for the 16S rRNA gene sequence of strain $\mathrm{R}^{\top}{ }^{\top}$ is DO912930.

A figure showing the gamma-radiation survival curves of strain $\mathrm{R}^{\top}{ }^{\top}$, Deinococcus radiodurans DSM $20539^{\top}$ and Escherichia coli $\mathrm{K} 12$ is available as supplementary material with the online version of this paper.
Strain $\mathrm{R}^{\mathrm{T}}{ }^{\mathrm{T}}$ was isolated from a modified Bennett's agar plate (Jones, 1949), which had been inoculated with a soil suspension and incubated at $28{ }^{\circ} \mathrm{C}$ for 14 days. The soil sample was collected from radiation-contaminated soil in the Xinjiang Uigur Autonomous Region of north-west China. The organism was maintained on inorganic saltsstarch agar slopes (ISP medium 4; Difco) (Shirling \& Gottlieb, 1966) at $4{ }^{\circ} \mathrm{C}$ and as a mixture of mycelial fragments and spores in $20 \%(\mathrm{v} / \mathrm{v})$ glycerol at $-20{ }^{\circ} \mathrm{C}$. Biomass for chemotaxonomic and molecular systematic studies was grown in shake flasks of modified Bennett's broth for up to 7 days at $28{ }^{\circ} \mathrm{C}$, harvested by centrifugation and washed twice in distilled water; cells for chemical studies were freeze-dried.

Extraction of genomic DNA, PCR-mediated amplification of the 16S rRNA gene and purification of the products from isolate $\mathrm{R}^{\mathrm{T}}{ }^{\mathrm{T}}$ were achieved following the procedures of Chun \& Goodfellow (1995). The PCR products were sequenced directly by using a Taq DyeDeoxy Terminator cycle sequencing kit (Applied Biosystems) and an Applied Biosystems 373A DNA sequencer. The resultant sequence (1442 nt) was aligned manually with corresponding sequences of available streptomycetes drawn from the 
DDBJ/EMBL/GenBank databases. The program MEGA version 3.1 (Kumar et al., 2004) was used for both multiple alignment and phylogenetic analyses. Phylogenetic trees were generated via the neighbour-joining (Saitou \& Nei, 1987) and maximum-parsimony (Fitch, 1971) tree-making algorithms; evolutionary distances for the neighbourjoining algorithm were calculated with the Kimura twoparameter model (Kimura, 1980). The topologies of the resultant trees were evaluated in a bootstrap analysis (Felsenstein, 1985) based on 1000 replicates. It was apparent from the initial neighbour-joining analysis, including more than 500 related sequences of Streptomyces type strains, that isolate $\mathrm{R} 97^{\mathrm{T}}$ represented a bona fide member of the genus Streptomyces (data not shown).

The new isolate was examined for a range of chemotaxonomic and morphological properties known to be characteristic of members of the genus Streptomyces (Williams et al., 1989). To this end, hyphal and spore chain arrangement were observed on modified Bennett's and inorganic salts-starch agar plates after incubation at $28{ }^{\circ} \mathrm{C}$ for 14 days, by using the coverslip technique of Kawato \& Shinobu (1959). Spore chain morphology and spore surface ornamentation were observed by examining gold-coated dehydrated specimens under an FEI QUANTA scanning electron microscope. The isomers of diaminopimelic acid and whole-organism sugars were analysed by using the procedures developed by Hasegawa et al. (1983) and Lechevalier \& Lechevalier (1980). Polar lipids were examined and identified according to the method of Minnikin et al. (1984), and fatty acids were extracted, methylated and analysed via GC by using the standard Sherlock MIDI (Microbial Identification) system (Sasser, 1990; Kämpfer \& Kroppenstedt, 1996). Menaquinones were extracted and purified following the method of Collins (1985) and then analysed by HPLC. The DNA
$\mathrm{G}+\mathrm{C}$ content of the strain was determined by using the thermal denaturation method of Marmur \& Doty (1962) with Escherichia coli K12 as a control.

Morphological and chemical characteristics of isolate $\mathrm{R} 97^{\mathrm{T}}$ were in line with its assignment to the genus Streptomyces (Williams et al., 1989; Manfio et al., 1995). The organism formed an extensively branched substrate mycelium, with aerial hyphae that differentiated into rough to warty, ovalshaped spores $(0.70-1.0 \times 0.92-1.4 \mu \mathrm{m})$ in spiral spore chains (Fig. 1). It contained major amounts of LL-diaminopimelic acid in whole-organism hydrolysates, hexahydrogenated and octahydrogenated menaquinones with nine isoprene units $\left[\mathrm{MK}-9\left(\mathrm{H}_{6}, \mathrm{H}_{8}\right)\right]$ as predominant isoprenologues and diphosphatidylglycerol and phosphatidylethanolamine as major polar lipids (phospholipid type II sensu Lechevalier et al., 1977), but lacked mycolic acids and characteristic sugars. The fatty acid profile was rich in saturated straight-chain and iso- and anteiso-branched components (fatty acid type 2c sensu Kroppenstedt, 1985). The DNA G + C content was $72.7 \mathrm{~mol} \%$.

Strain $\mathrm{R}^{\mathrm{T}}{ }^{\mathrm{T}}$ was compared with its closest phylogenetic neighbours by using the procedures described above. It was evident from the phylogenetic tree thus constructed (Fig. 2) that the organism formed a distinct phyletic line together with the type strains of Streptomyces macrosporus and Streptomyces megasporus, an association that was supported by both of the tree-making algorithms employed and by a $99 \%$ bootstrap value in the neighbour-joining analysis. Strain $\mathrm{R}^{\mathrm{T}}{ }^{\mathrm{T}}$ shared highest $16 \mathrm{~S}$ rRNA gene sequence similarity with S. macrosporus NBRC $14748^{\mathrm{T}}$ (97.5\%), which corresponds to $35 \mathrm{nt}$ differences at 1444 locations with gaps, and lower values with $S$. megasporus NBRC $14749^{\mathrm{T}}(96.7 \%)$ and Streptomyces thermolineatus NBRC $14750^{\mathrm{T}}(97.1 \%)$. DNA-DNA relatedness studies were not
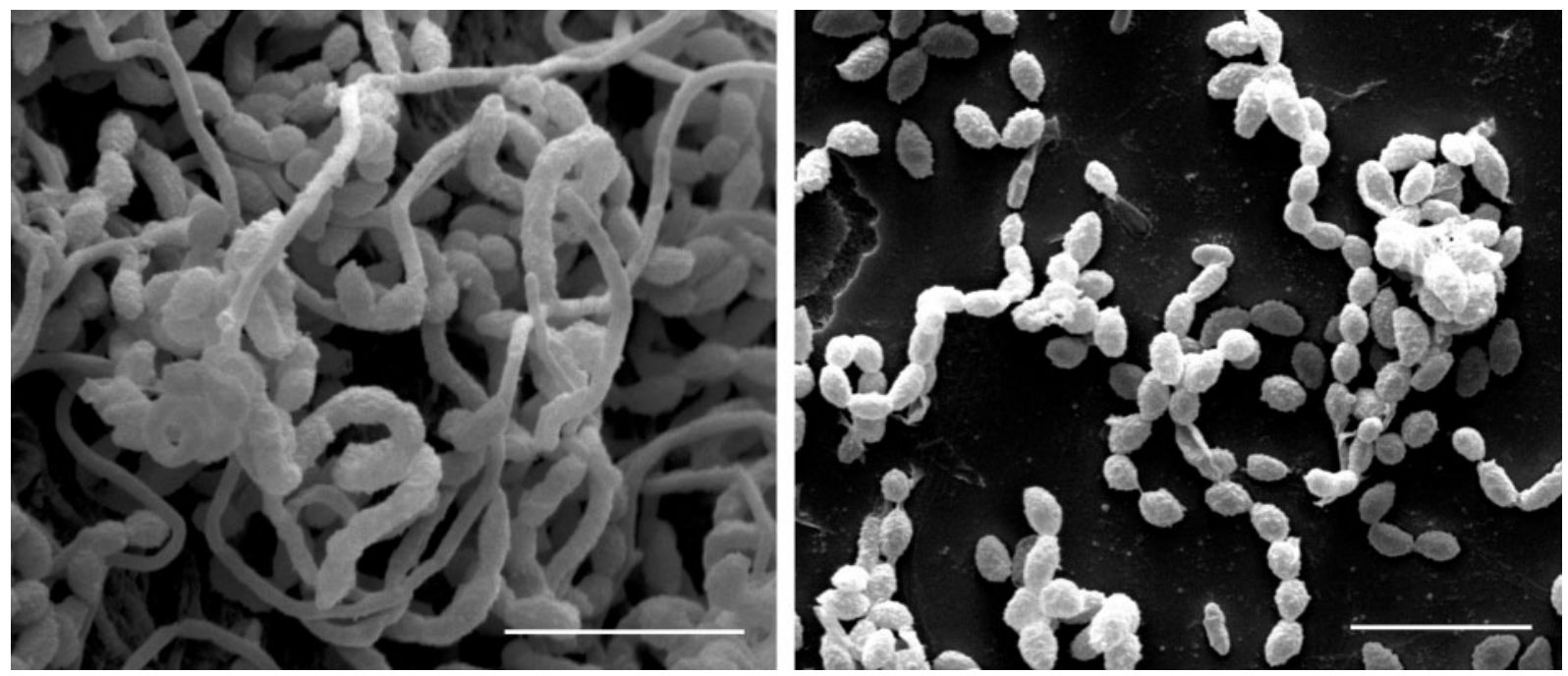

Fig. 1. Scanning electron micrographs of strain $\mathrm{R} 97^{\top}$ showing spiral chains of rough to warty spores after growth on inorganic salts-starch agar for 14 days at $28^{\circ} \mathrm{C}$. Bars, $5 \mu \mathrm{m}$. 


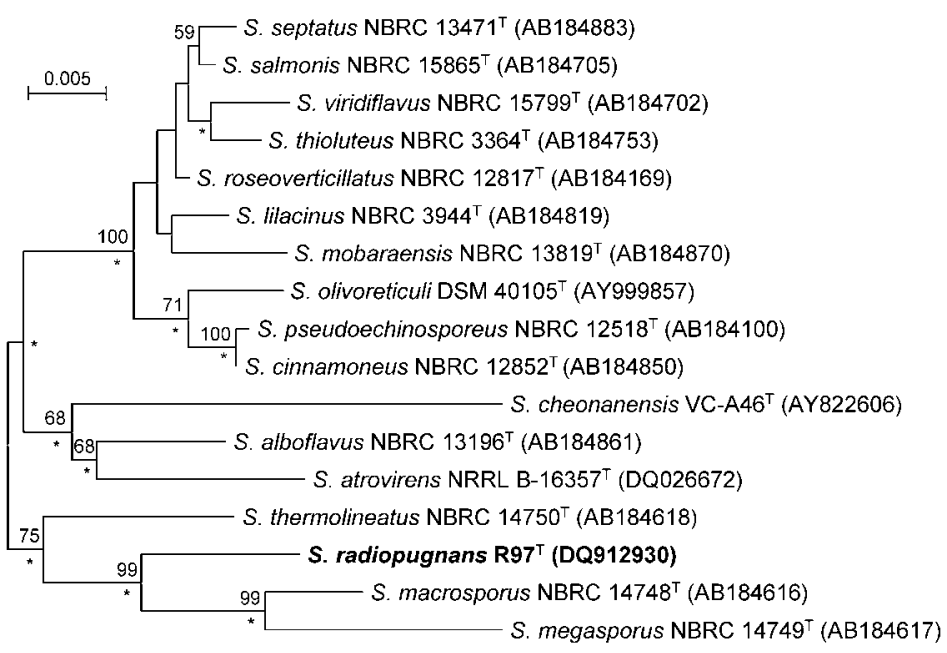

Fig. 2. Neighbour-joining tree based on nearly complete 16S rRNA gene sequences showing relationships between strain $\mathrm{R}^{\top} 7^{\top}$ and the type strains of phylogenetically close Streptomyces species. Asterisks indicate branches of the tree that were also recovered with the maximum-parsimony tree-making algorithm. Numbers at nodes are percentage bootstrap values based on 1000 resampled data sets; only values above $50 \%$ are given. Bar, 0.005 substitutions per nucleotide position.

carried out between strain $\mathrm{R} 97^{\mathrm{T}}$ and these organisms as representatives of several Streptomyces species with much higher 16S rRNA gene sequence similarities have DNA-DNA relatedness values well below the $70 \%$ cutoff point recommended for the delineation of genomic species (Wayne et al., 1987), as exemplified in a study on neutrotolerant acidophilic streptomycetes ( $\mathrm{Xu}$ et al., 2006).
The organism was also examined for a range of phenotypic properties. Colonial and pigmentation features were observed on inorganic salts-starch agar (ISP medium 4), and yeast extract-malt extract agar (ISP medium 2; Difco), and on modified Bennett's agar, Gauze's synthetic medium no. 1 agar (DSMZ medium no. 1048) and yeast-starch agar (DSMZ medium no. 1027) after incubation for 14 days at $28{ }^{\circ} \mathrm{C}$. Similarly, peptone-yeast extract-iron and tyrosine

Table 1. Phenotypic properties that differentiate strain $R 97^{\top}$ from representatives of phylogenetically close Streptomyces species

All strains grew at $45{ }^{\circ} \mathrm{C}$. Data are taken from the present study and from Goodfellow et al. (1987). +, Positive; - , negative; $+{ }^{w}$, weakly positive.

\begin{tabular}{|c|c|c|c|c|}
\hline Characteristic & Strain $\mathrm{R} 7^{\mathrm{T}}$ & 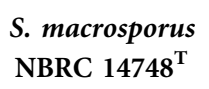 & 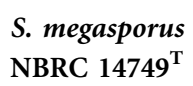 & 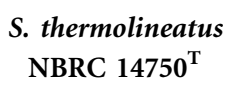 \\
\hline Spore chain morphology & Spiral & Spiral & Spiral & Rectiflexibiles \\
\hline Spore surface ornamentation & Rough to warty & Warty & Warty & Smooth \\
\hline \multicolumn{5}{|l|}{ Degradation of: } \\
\hline Elastin & - & - & + & - \\
\hline Xanthine & + & - & - & - \\
\hline \multicolumn{5}{|l|}{ Growth on sole carbon sources } \\
\hline Inositol & - & + & - & - \\
\hline Inulin & + & $+{ }^{w}$ & - & - \\
\hline Mannitol & + & - & - & $+{ }^{w}$ \\
\hline L-Rhamnose & + & + & $t^{\mathrm{w}}$ & - \\
\hline Sucrose & + & - & - & - \\
\hline Trehalose & - & + & - & + \\
\hline Xylitol & + & - & - & - \\
\hline D-Xylose & + & + & - & - \\
\hline Sodium citrate & + & - & - & - \\
\hline \multicolumn{5}{|l|}{ Growth at: } \\
\hline $\mathrm{pH} 5$ & + & - & - & - \\
\hline $\mathrm{pH} 11$ & + & + & - & + \\
\hline \multicolumn{5}{|c|}{ Growth on sole nitrogen sources } \\
\hline $\mathrm{KNO}_{3}$ & - & + & - & + \\
\hline L-Cysteine & + & - & - & - \\
\hline L-Phenylalanine & - & + & - & + \\
\hline
\end{tabular}


agars (Shirling \& Gottlieb, 1966) were examined for the production of melanin pigments. Additional phenotypic properties were determined by using established media and methods (Williams et al., 1983; Kämpfer et al., 1991). The various media supported the growth of a white to grey aerial spore mass and a range of substrate mycelial pigments. Melanin pigments were not formed on either peptone-yeast extract-iron or tyrosine agars. It is evident from Table 1 that strain $\mathrm{R} 97^{\mathrm{T}}$ can be distinguished from its closest phylogenetic neighbours based on a combination of phenotypic properties, although like them it is thermotolerant.

The survival rate of strain $\mathrm{R}^{\mathrm{T}}{ }^{\mathrm{T}}$ in response to gamma radiation was compared with those of Deinococcus radiodurans DSM $20539^{\mathrm{T}}$ (radiation-resistant organism) and Escherichia coli K12 (radiation-sensitive organism) via an established procedure (Ferreira et al., 1997; Chen et al., 2004). The strains were grown in modified Bennett's broth (containing glass beads to prevent mycelium formation) to exponential growth phase, at which point biomass was washed with sodium chloride $(0.85 \%, \mathrm{w} / \mathrm{v})$, centrifuged at $4{ }^{\circ} \mathrm{C}$ and resuspended in saline $(0.85 \%, \mathrm{w} / \mathrm{v})$ to give a concentration of $1 \times 10^{7}-1 \times 10^{8}$ c.f.u. $\mathrm{ml}^{-1}$. Each suspension was divided into $2-\mathrm{ml}$ aliquots and exposed to a ${ }^{60} \mathrm{Co}$ source at a dose rate of $0.167 \mathrm{kGy} \min ^{-1}$ at room temperature $\left(1 \mathrm{kGy}=10^{5} \mathrm{rads}\right)$; the gamma radiation doses were from zero to $20.0 \mathrm{kGy}$ in steps of $2.5 \mathrm{kGy}$. Treated samples were diluted and plated in triplicate onto modified Bennett's agar plates and then incubated at $28{ }^{\circ} \mathrm{C}$ for 15 days, at which point the colony-forming units were counted. Viability was assessed by using non-irradiated suspensions of each strain under the same conditions as the controls.

Strain $\mathrm{R} 97^{\mathrm{T}}$ was resistant to gamma radiation with a shoulder dose (the dose required before the number of colonyforming units began to decline) of $5 \mathrm{kGy}$, a result comparable with the shoulder dose for D. radiodurans DSM $20539^{\mathrm{T}}$. Exposure of the two radiation-resistant strains to $15 \mathrm{kGy}$ resulted in survival rates for strain $\mathrm{R} 97^{\mathrm{T}}$ and $D$. radiodurans DSM $20539^{\mathrm{T}}$ of 1 and $2.6 \%$, respectively (see Supplementary Fig. S1 in IJSEM Online). Consequently, strain R97 ${ }^{\mathrm{T}}$ can be added to the taxonomically diverse group of thermotolerant/ thermophilic bacteria that are able to resist gamma radiation (Mattimore \& Battista, 1996; Ferreira et al., 1997, 1999). It is not clear how such organisms have acquired their ability to resist radiation damage, although there is evidence that it may be due to evolutionary processes resulting from environmental stress, particularly that caused by drought and heat (Mattimore \& Battista, 1996).

The genotypic and phenotypic data presented clearly demonstrate that strain $\mathrm{R}^{2} 7^{\mathrm{T}}$ represents a novel species of the genus Streptomyces, for which the name Streptomyces radiopugnans sp. nov. is proposed.

\section{Description of Streptomyces radiopugnans sp. nov.}

Streptomyces radiopugnans (ra.di.o.pug' nans. L. n. radius a beam or ray; N.L. pref. radio- pertaining to radiation; L. part. adj. pugnans fighting or resisting; N.L. part. adj. radiopugnans radiation-resisting).

Aerobic, Gram-positive, radiation-resistant actinomycete that forms an extensively branched substrate mycelium which carries aerial hyphae that differentiate into spiral chains of spores with rough to warty surfaces. Moderate to abundant, white to pale-grey aerial spore mass is formed on modified Bennett's, Gauze's synthetic medium no. 1, inorganic salts-starch, yeast extract-malt extract and yeaststarch agars. Substrate mycelium is yellowish brown on modified Bennett's, Gauze's no. 1 and yeast-starch agars and light pinkish yellow on inorganic salts-starch and yeast extract-malt extract agars. Diffusible pigments are not formed on any of the media, and melanin pigments are not formed on peptone-yeast extract-iron or tyrosine agars. Growth occurs between 20 and $50{ }^{\circ} \mathrm{C}$, but not at $55{ }^{\circ} \mathrm{C}$. Growth also occurs in the presence of $0.1 \%$ phenol, but not in the presence of $7 \% \mathrm{NaCl}$. Tween 60 is degraded, but Tweens 20 and 80 are not. L-Arabinose, L-melezitose and L-ribose are used as sole carbon sources for energy and growth, but not L-cellobiose, L-lactose, L-lactulose, L-melibiose, D-raffinose or trehalose (all at 1\%,w/v). Similarly, L-cysteine, L-glycine, D-glutamate, sodium azelate, sodium isobutyrate and sodium malonate are used as sole carbon sources for energy and growth, but not D-glutamic acid, hydroxy-L-proline, DL-isoleucine, L-leucine, methyl Dglucopyranoside, methyl $\alpha$-D-mannopyranoside, L-phenylalanine, sodium propionate, sodium pyruvate, sodium suberate or spermidine (all at $0.1 \%, \mathrm{w} / \mathrm{v}$ ). Additional phenotypic properties are given in Table 1. The fatty acid profile consists of iso- $\mathrm{C}_{16: 0}(34.5 \%)$, anteiso- $\mathrm{C}_{15: 0}$ $(15.4 \%)$, iso- $\mathrm{H}-\mathrm{C}_{16: 1}(14.2 \%)$, anteiso- $\mathrm{C}_{17: 0}(9.1 \%)$, iso$\mathrm{C}_{14: 0}(5.6 \%)$ and anteiso- $\mathrm{C}_{17: 1} \omega 9 c(5.2 \%)$. The DNA $\mathrm{G}+\mathrm{C}$ content is $72.7 \mathrm{~mol} \%$.

The type strain, $\mathrm{R}^{\mathrm{T}}{ }^{\mathrm{T}}\left(=\right.$ CGMCC $\left.4.3519^{\mathrm{T}}=\mathrm{DSM} 41901^{\mathrm{T}}\right)$, was isolated from a radiation-contaminated soil sample collected from Xinjiang Province, north-west China. The species description is based on a single strain and hence serves as a description of the type strain.

\section{Acknowledgements}

This research was supported by the Hi-Tech Research and Development Program of China (grant no. 2004AA227110), Knowledge Innovation Program of the Chinese Academy of Sciences (KSCX2YW-Z-042) and through the Royal Society-Chinese Academy of Sciences Exchange Scheme (grant no. Q814). We are grateful to Ms Wen Zheng for help with the menaquinone analysis and with deposition of the strain in the culture collections.

\section{References}

Albuquerque, L., Simoes, C., Nobre, M. F., Pino, N. M., Battista, J. R., Silva, M. T., Rainey, F. A. \& da Costa, M. S. (2005). Truepera radiovictrix gen. nov., sp. nov., a new radiation resistant species and the proposal of Trueperaceae fam. nov. FEMS Microbiol Lett 247, 161-169. 
Anderson, A. W., Nordan, H. C., Cain, R. F., Parrish, G. \& Duggan, D. (1956). Studies on a radio-resistant Micrococcus. I. Isolation, morphology, cultural characteristics, and resistance to gamma radiation. Food Technol 10, 575-577.

Brooks, B. W. \& Murray, R. G. E. (1981). Nomenclature for "Micrococcus radiodurans" and other radiation-resistant cocci: Deinococcaceae fam. nov. and Deinococcus gen. nov., including five species. Int J Syst Bacteriol 31, 353-360.

Chen, M. Y., Wu, S. H., Lin, G. H., Lu, C. P., Lin, Y. T., Chang, W. C. \& Tsay, S. S. (2004). Rubrobacter taiwanensis sp. nov., a novel thermophilic, radiation-resistant species isolated from hot springs. Int J Syst Evol Microbiol 54, 1849-1855.

Chun, J. \& Goodfellow, M. (1995). A phylogenetic analysis of the genus Nocardia with 16S rRNA gene sequences. Int J Syst Bacteriol 45, 240-245.

Collins, M. D. (1985). Isoprenoid quinone analysis in classification and identification. In Chemical Methods in Bacterial Systematics, pp. 267-287. Edited by M. Goodfellow \& D. E. Minnikin. London: Academic Press.

Collins, M. D., Hutson, R. A., Grant, I. R. \& Patterson, M. F. (2000). Phylogenetic characterization of a novel radiation-resistant bacterium from irradiated pork: description of Hymenobacter actinosclerus sp. nov. Int J Syst Evol Microbiol 50, 731-734.

Felsenstein, J. (1985). Confidence limits on phylogenies: an approach using the bootstrap. Evolution 39, 783-791.

Ferreira, A. C., Nobre, M. F., Rainey, F. A., Silva, M. T., Wait, R., Burghardt, J., Chung, A. P. \& da Costa, M. S. (1997). Deinococcus geothermalis sp. nov. and Deinococcus murrayi sp. nov., two extremely radiation-resistant and slightly thermophilic species from hot springs. Int J Syst Bacteriol 47, 939-947.

Ferreira, A. C., Nobre, M. F., Moore, E., Rainey, F. A., Battista, J. R. \& da Costa, M. S. (1999). Characterization and radiation resistance of new isolates of Rubrobacter radiotolerans and Rubrobacter xylanophilus. Extremophiles 3, 235-238.

Fitch, W. M. (1971). Toward defining the course of evolution: minimum change for a specific tree topology. Syst Zool 20, 406-416.

Goodfellow, M., Lacey, J. \& Todd, C. (1987). Numerical classification of thermophilic streptomycetes. J Gen Microbiol 133, 3135-3149.

Hasegawa, T., Takizawa, M. \& Tanida, S. (1983). A rapid analysis for chemical grouping of aerobic actinomycetes. J Gen Appl Microbiol 29, 319-322.

Jones, K. L. (1949). Fresh isolates of actinomycetes in which the presence of sporogenous aerial mycelia is a fluctuating characteristic. J Bacteriol 57, 141-145.

Kämpfer, P. \& Kroppenstedt, R. M. (1996). Numerical analysis of fatty acid patterns of coryneform bacteria and related taxa. Can J Microbiol 42, 989-1005.

Kämpfer, P., Kroppenstedt, R. M. \& Dott, W. (1991). A numerical classification of the genera Streptomyces and Streptoverticillium using miniaturized physiological tests. J Gen Microbiol 137, 1831-1891.

Kawato, M. \& Shinobu, R. (1959). On Streptomyces herbaricolor sp. nov., supplement: a single technique for microscopical observation. Mem Osaka Univ Lib Arts Educ B Nat Sci 8, 114-119.

Kimura, M. (1980). A simple method for estimating evolutionary rates of base substitutions through comparative studies of nucleotide sequences. J Mol Evol 16, 111-120.

Kroppenstedt, R. M. (1985). Fatty acid and menaquinone analysis of actinomycetes and related organisms. In Chemical Methods in
Bacterial Systematics, pp. 179-199. Edited by M. Goodfellow \& D. E. Minnikin. London: Academic Press.

Kumar, S., Tamura, K. \& Nei, M. (2004). MEGA3: integrated software for molecular evolutionary genetics analysis and sequence alignment. Brief Bioinform 5, 150-163.

Lechevalier, H. \& Lechevalier, M. P. (1980). The chemotaxonomy of actinomycetes. In Actinomycete Taxonomy (Special Publication 6), pp. 277-284. Edited by A. Dietz \& D. W. Thayer. Arlington, VA: Society of Industrial Biology.

Lechevalier, M. P., De Bièvre, C. \& Lechevalier, H. A. (1977). Chemotaxonomy of aerobic actinomycetes: phospholipid composition. Biochem Syst Ecol 5, 249-260.

Manfio, G. P., Zakrzewska-Czerwinska, J., Atalan, E. \& Goodfellow, M. (1995). Towards minimal standards for the description of Streptomyces species. Biotechnologia 7-8, 242-263.

Marmur, J. \& Doty, P. (1962). Determination of base composition of deoxyribonucleic acid from its denaturation temperature. J Mol Biol 5, 109-118.

Mattimore, V. \& Battista, J. R. (1996). Radioresistance of Deinococcus radiodurans: functions necessary to survive ionizing radiation are also necessary to survive prolonged desiccation. J Bacteriol 178, 633-637.

Minnikin, D. E., O'Donnell, A. G., Goodfellow, M., Alderson, G., Athalye, M., Schaal, A. \& Parlett, J. H. (1984). An integrated procedure for the extraction of isoprenoid quinones and polar lipids. J Microbiol Methods 2, 233-241.

Phillips, R. W., Wiegel, J., Berry, C. J., Fliermans, C., Peacock, A. D., White, D. C. \& Shimkets, L. J. (2002). Kineococcus radiotolerans sp. nov., a radiation-resistant, gram-positive bacterium. Int J Syst Evol Microbiol 52, 933-938.

Saitou, N. \& Nei, M. (1987). The neighbor-joining method: a new method for reconstructing phylogenetic trees. Mol Biol Evol 4, 406-425.

Sasser, M. (1990). Identification of bacteria by gas chromatography of cellular fatty acids, MIDI Technical Note 101. Newark, DE: MIDI Inc.

Shirling, E. B. \& Gottlieb, D. (1966). Methods for characterization of Streptomyces species. Int J Syst Bacteriol 16, 313-340.

Venkateswaran, K., Kempf, M., Chen, F., Satomi, M., Nicholson, W. \& Kern, R. (2003). Bacillus nealsonii sp. nov., isolated from a spacecraftassembly facility, whose spores are gamma-radiation resistant. Int $J$ Syst Evol Microbiol 53, 165-172.

Wayne, L. G., Brenner, D. J., Colwell, R. R., Grimont, P. A. D., Kandler, O., Krichevsky, M. I., Moore, L. H., Moore, W. E. C., Murray, R. G. E. \& other authors (1987). International Committee on Bacterial Systematics. Report of the ad hoc committee on reconciliation of approaches to bacterial systematics. Int J Syst Bacteriol 37, 463-464.

Williams, S. T., Goodfellow, M., Alderson, G., Wellington, E. M. H., Sneath, P. H. A. \& Sackin, M. J. (1983). Numerical classification of Streptomyces and related genera. J Gen Microbiol 129, 1743-1813.

Williams, S. T., Goodfellow, M. \& Alderson, G. (1989). Genus Streptomyces Waksman and Henrici 1943, 339 ${ }^{\mathrm{AL}}$. In Bergey's Manual of Systematic Bacteriology, vol. 4, pp. 2452-2492. Edited by S. T. Williams, M. E. Sharpe \& J. G. Holt. Baltimore: Williams \& Wilkins.

Xu, C., Wang, L., Cui, O., Huang, Y., Liu, Z., Zhang, G. \& Goodfellow, M. (2006). Neutrotolerant acidophilic Streptomyces species isolated from acidic soils in China: Streptomyces guanduensis sp. nov., Streptomyces paucisporeus sp. nov., Streptomyces rubidus sp. nov. and Streptomyces yanglinensis sp. nov. Int J Syst Evol Microbiol 56, $1109-1115$. 